\title{
HUBUNGAN BEBAN KERJA DENGAN KINERJA PELAPORAN DATA PELAYANAN KESEHATAN IBU DAN ANAK DI KOTA SEMARANG
}

\author{
Asti Dwi Noverina ${ }^{1}$, Sutaip ${ }^{2}$, Nurizqi Salsa Ramdhani ${ }^{3}$ \\ 1,2,3 Jurusan Administrasi Kesehatan, Sekolah Tinggi IImu Kesehatan Brebes \\ Indonesia
}

\begin{abstract}
The implementation of the maternal and childh health program cannot be separated from recording and reporting as documentation and evaluation of all activities that have been carried out. The implementation of the KIA program starts from maternity huts, sub-health centers, private service facilities which are finally collected from monthly monitoring reports on maternal and child health areas. In fact, the Central Statistics Agency has not carried out data reporting properly, namely the Central Statistics Agency does not report maternal and childh health program service data, reports are not timely and reporting reports are incomplete. The purpose of this research is as an effort to improve puskesmas through planning, implementing, monitoring, controlling and assessing so that it can provide quality, relevant and valid information. Observational research using survey method with cross sectional approach. The independent variable studied is workload and the dependent variable is the performance of reporting data on maternal and childh health program services. The sampling technique was proportional random sampling at 35 Puskesmas to determine the number of samples in each strata/region and simple random sampling to determine the sample in each selected area. Data processing using the stages of editing, coding, entry, and tabulating. Analysis of the data used is univariate analysis with frequency and percentage distributions and bivariate analysis with statistical tests using Spearman's Rank Correlation test. Based on the results of statistical tests using Spearman's Rank Correlation, $p$ value $=0.001(p<0.05)$. This shows that there is a significant relationship between workload and reporting performance of maternal and childh health program a service data. The Efforts of the Health Office and Puskesmas to provide rewards for the performance of officers in recording and reporting of maternal and childh health program data, so that help make the KIA program a success. The implementation of the Maternal and Child Health program cannot be separated from recording and reporting as documentation and evalution of all activities that have been carried out
\end{abstract}

Keywords : workload; private practice midwife; maternal and child health service 


\section{PENDAHULUAN}

Angka kematian ibu di Indonesia diperkirakan 300-400 per 100.000 kelahiran hidup, yang berarti bahwa di Indonesia seorang ibu meninggal setiap jam baik karena kehamilan itu sendiri, komplikasi saat persalinan, rujukan yang terlambat ke rumah sakit, ataupun pelayanan darurat obstetri yang kurang baik. Penyebab kematian maternal di Indonesia sebanyak 28\% disebabkan oleh perdarahan, preeklampsia dan eklampsia (24\%), infeksi atau sepsis (11\%), komplikasi akibat abortus (6\%), persalinan terhambat $(5 \%)$, dan penyebab lain. (Prihesti et al., 2019)

Pelaksanaan program KIA terdiri dari kegiatan pencatatan dan pelaporan sebagai bahan dokumentasi dan evaluasi atas seluruh kegiatan yang dilakukan. Pelaksanaan program kesehatan ibu dan anak dimulai dari rumah bersalin (polindes), Puskesmas pembantu, sarana pelayanan Swasta yang akhirnya dikumpulkan di Puskesmas, kemudian dilaporkan dalam bentuk laporan bulanan kepada unit Dinas Kesehatan Kabupaten/Kota dalam untuk Pemantuan Wilayah Setempat Kesehatan Ibu dan Anak (PWS-KIA). (L. E. S. Bustami et al., 2017)

Pemanfaatan data laporan PWSKIA untuk memenuhi kebutuhan administrasi pada jenjang yang lebih tinggi dalam rangka pembinaan, penetapan kebijaksanaan dan dimanfaatkan oleh puskesmas untuk peningkatan upaya kesehatan puskesmas, melalui perencanaan, penggerakan, pelaksanaan, pengawasan, pengendalian, dan penilaian. Selain itu berfungsi untuk petugas di tingkat puskesmas lebih bertanggung jawab dalam mencatat seluruh upaya kesehatan yang dilaksanakannya dan melaporkan secara teratur dan tepat waktu serta mampu memanfaatkan data dan informasi dari data system pencatatan dan pelaporan terpadu puskesmas (SP2TP) sehingga dapat memberikan umpan balik. Informasi dapat dikatakan berkualitas apabila tepat waktu (timeliness), Relevan, Valid/ akurat, presise dan biaya yang layak. (Suryani, 2013)

Berdasarkan hasil Studi pendahuluan pada bulan Januari - Maret 2019 ditemukan adanya beberapa kendala dalam pelaporan data pelayanan KIA yang dilakukan oleh BPS ke Dinas Kesehatan Kota Semarang. Diantaranya yaitu BPS terlambat mengirim laporan ke dinas kesehatan dalam setiap bulannya. Data tersebuat akan digunakan oleh dinas Kesehatan dalam memantau status kesehatan masyarakat. Hal ini juga menyebabkan penyusunan profil Kesehatan Semarang mengalami keterlambatan sehingga menyebabkan informasi yang diberikan kepada 
masyarakat tidak terkini lagi dan laporan tidak segera dapat digunakan sebagai bahan evaluasi program kerja

Mengadopsi model kinerja Gibson (Gibson et al., 2012) kinerja bidan dalam memberikan pelayanan KIA dipengaruhi oleh beberapa faktor yaitu faktor individu (tingkat pengetahuan, masa kerja, status kepegawaian, keluarga, demografis), faktor organisasi (supervisi, fasilitas kerja, pelatihan dan pengembangan, beban kerja, sumber daya, struktur, imbalan, kepemimpinan), dan faktor psikologis (motivasi, sikap, persepsi, kepribadian, etika kerja, rancangan tugas.

\section{METODOLOGI PENELITIAN}

Penelitian ini merupakan penelitian survei analitik dengan tipe eksplanatory research dengan pendekatan cross sectional study bertujuan untuk menjelaskan hubungan variabel bebas yaitu Beban kerja dengan variabel terikat yaitu kinerja pelaporan data pelayanan Kesehatan Ibu dan Anak (KIA) di Kota Semarang melalui pengujian hipotesis. Populasi dalam penelitian ini adalah seluruh Bidan Praktek Swasta yang melakukan pelaporan di puskesmas di Kota Semarang yang berjumlah 222 orang dan jumlah sampel yang digunakan adalah 68 responden. Teknik pengambilan sampel adalah proporsional random sampling pada 35 Puskesmas untuk menentukan jumlah sampel di setiap strata/wilayah dan simple random sampling untuk menentukan sampel pada setiap wilayah yang terpilih. Pengolahan data dengan menggunakan tahapan editing, koding, entry, dan tabulating. Analisa data yang digunakan adalah analisa univariat dengan distribusi frekuensi dan persentase dan analisa bivariat dengan uji statistic menggunakan uji Korelasi Rank Spearman. (Sukidjo Notoatmodjo, 2012)

\section{HASIL PENELITIAN DAN BAHASAN}

\section{Analisa Univariat}

Beban Kerja

Tabel. 1 Distribusi Frekuensi Beban Kerja dalam Pelaporan Data Pelayanan KIA di Kota Semarang

\begin{tabular}{llrl}
\hline No & $\begin{array}{c}\text { Beban Kerja } \\
\text { responden }\end{array}$ & f & $\%$ \\
\hline 1. & Kurang Baik & 34 & 50,0 \\
2. & Baik & 34 & 50,0 \\
\hline & Total & 68 & 100,0 \\
\hline & Berdasarkan & hasil & penelitian
\end{tabular}
didapatkan bahwa responden dengan beban kerja untuk kategori beban kerja kurang baik dan kategori beban kerja baik persentasenya sama besar (50\%) (tabel 1). Menurut Azwar (Azwar, 2013), bahwa beban kerja adalah penggunanan waktu kerja yang di perlukan oleh seseorang untuk menyelesaikan pekerjaannya. Pada item pertanyaan sebagian responden memiliki beban kerja yang baik. Namun demikian responden beranggapan bahwa dengan adanya pelayanan responden merasa telat (60,3\%) dan responden merasa tidak lengkap (50,0\%) melaporkan data pelayanan KIA ke puskesmas, 
responden merasa pekerjaan pelaporan data pelayanan KIA yang diberikan oleh Puskesmas terlalu banyak (51,5\%). Hal ini berakibat pada pelaporan yang tidak tepat waktu dan lengkap.

\section{Kinerja pelaporan data pelayanan KIA}

Tabel. 2 Distribusi Frekuensi Kinerja Dalam Pelaporan Data Pelayanan KIA Di Kota Semarang

\begin{tabular}{llcc}
\hline No & $\begin{array}{c}\text { Persepsi } \\
\text { responden }\end{array}$ & $\mathrm{f}$ & $\%$ \\
\hline 1. & Kurang Baik & 25 & 36,8 \\
\hline 2. & Baik & 43 & 63,2 \\
& Total & 68 & 100,0 \\
\hline
\end{tabular}

Berdasarkan hasil penelitian didapatkan bahwa sebagian besar responden memiliki kinerja baik $(63,2 \%)$ (tabel 2) dalam pelaporan data pelayanan KIA. Hal ini didukung oleh Gibson (Gibson et al., 2012), bahwa kinerja adalah hasil yang diinginkan dan perilaku. Kinerja individu merupakan dasar dari kinerja organisasi. Berdasarkan hasil observasi yang dilakukan peneliti terhadap kinerja pelaporan data diperoleh bahwa dari segi kelengkapan data pelayanan KIA bulan maret dengan rata-rata $70,47 \%$, april $71,94 \%$. Data yang tidak lengkap seperti data ibu nifas, ibu hamil yang dirujuk, deteksi resiko tinggi dan kunjungan neonatus. Hal ini dikarenakan sebagian Puskesmas tidak menyedikan kolom formulir data tersebut, sehingga BPS tidak melaporkan data tersebut ke Puskesmas. Walapun pada kenyataanya Dinas kesehatan dan Puskesmas sendiri meminta laporan data tersebut. Dan dari segi ketepatan waktu pelaporan data pelayanan KIA bulan maret $34,31 \%$, april $32,48 \%$, meskipun ada BPS tidak melakukan pelaporan data pelayanan KIA sama sekali (13,2\%). Hal ini banyak dikeluhkan oleh Bidan Koordinator karena kan menggangu kelancaran tugas Bidan Koordinator dalam melaksanakan pelaporan ke Dinas Kesehatan.

\section{Hubungan antara beban kerja dengan kinerja pelaporan data pelayanan KIA}

Berdasarkan hasil uji statistik dengan menggunakan Korelasi Rank Spearman diperoleh nilai $p=0,001$ $(p<0,05)$. Hal ini menunjukkan bahwa ada hubungan bermakna antara beban kerja dengan Kinerja pelaporan data pelayanan KIA. Dengan nilai koefisien korelasi ( $r=0$, 381) menggambarkan korelasi yang lemah. Kemudian nilai positif menggambarkan hubungan yang searah. Beban kerja yang dimiliki bagi Bidan Praktek swasta dapat memberikan pengaruh terhadap kemampuan kerja yang dilaksanakan dimanah hal ini berhubungan dengan maksimalisasi hasil kerja demi memberikan kepuasan dan kualitas pelaksanaan pelaporan data pelayanan KIA. Beban kerja yang kurang baik bagi BPS membawa akibat yang tidak dinginkan oleh jajaran kesehatan yaitu terbengkalainya program-program kesehatan terutama yang berhubungan dengan program pelaporan data pelayanan KIA. Menurut Suci Koesomowidjojo (Koesomowidjojo, 2017) 
beban kerja seseorang telah ditentukan dalam bentuk standar kerja perusahaaan menurut jenis pekerjaannya. Apabila sebagian besar karyawan bekerja sesuai dengan standar perusahaan, maka tidak menjadi masalah. Sebaliknya, jika karyawan bekerja dibawah standar maka beban kerja yang diemban berlebih. Sementara jika karyawan bekerja diatas standar, berarti estimasi standar yang ditetapkan lebih rendah dibanding kapasitas karyawan sendiri. Kebutuhan SDM dapat dihitung dengan mengidentifikasikan seberapa banyak output organisasi pada devisi tertentu yang ingin dicapai. Kemudian hal itu diterjemahkan dalam bentuk lamanya (jam dan hari) karyawan yang diperlukan untuk mencapai output tersebut, sehingga dapat diketahui pada jenis pekerjaan apa saja yang terjadi apakah negatif atau sesuai standar. (Suliantoro, 2021). Hasil penelitian ini sesuai dengan penelitian Linda Meliati (Melianti, 2012), bahwa ada hubungan antara persepsi beban kerja dengan kinerja bidan dalam deteksi dini resiko ibu hamil dikabupaten Lombok Timur.

Beban kerja adalah banyaknya jenis pekerjaan yang harus diselesaikan oleh tenaga kesehatan. profesional dalam satu tahun dalam satu sarana pelayanan kesehatan. Standar beban kerja adalah banyaknya jenis pekerjaan yang dapat dilaksanakan oleh seseorang tenaga kesehatan profesional dalam satu tahun kerja sesuai dengan standar profesional dan telah memperhitungkan waktu libur, sakit, dan lain-lain. (Siswati, 2018)

\section{KESIMPULAN}

Berdasarkan penilitian bahwa beban kerja dan kinerja pelaporan data pelayanan KIA di Kota Semarang tergolong baik, namun demikan masih ada beberapa hal kurang baik ditunjukkan dari jawaban beberapa item pertanyaan yang salah. Adanya hubungan antara beban kerja dengan kinerja pelaporan data pelayanan KIA. Bagi dinas kesehatan dan Puskesmas hendaknya meningkatakan motivasi BPS dalam pelaporan data pelayanan $\mathrm{KIA}$

\section{DAFTAR PUSTAKA}

1. Azwar, S. (2013). Sikap Manusia dan Pengukurannya. Pusat Belajar Offset.

2. Gibson, J. L., Ivancevich, J. M., Donelly, J. H., \& Konopaske, R. (2012). Organization: Behavior, Structure, Processes (14th ed.). Mc Graw Hills.

3. Koesomowidjojo, S. R. M. (2017). Panduan Praktis Menyusun Analisa Beban Kerja. Raih Asa Sukses.

4. L. E. S. Bustami, Insan, A. A., Iryan, D., \& Yulizawati. (2017). Buku Ajar Kebidanan Komunitas. CV. Rumah kayu Pustaka Utama.

5. Melianti, L. (2012). Faktor-Faktor Yang Mempengaruhi Kinerja Bidan Di Desa Dalam Kegiatan Deteksi Dini Resiko Tinggi lbu Hamil Di Wilayah 
Kerja Dinas Kesehatan Kabupaten

Lombok Timur. Jurnal Kesehatan

Prima, 6(2), 982-993.

http://poltekkes-mataram.ac.id/cp/wp-

content/uploads/2015/08/7.-982-993-

Linda-Melianti.pdf

6. Prihesti, U. S., Nurdiati, D. S., \& Ganap, E. P. (2019). Tren dan Faktor Risiko Kematian Maternal di RSUP Dr.Sardjito Yogyakarta tahun 20122017. Jurnal Kesehatan Reproduksi, $6(2)$, 44. https://doi.org/10.22146/jkr.46609

7. Siswati. (2018). Manajemen Unit Kerja II: Perencanaan SDM Unit Kerja RMIK (Pusat Pendidikan Sumber Daya Menusia (ed.)).

8. Sukidjo Notoatmodjo. (2012). Metode Penelitian Kesehatan Edisi Revisi. PT. Rineka Cipta.

9. Suliantoro. (2021). Pengaruh Beban Kerja Terhadap Produktivitas Kerja Karyawan Tenaga Non Kesehatan Di Unit Pelaksana Teknis Rumah Sakit .Jurnal Optimal, VIII(1), 79-88. https://jurnal.stieieu.ac.id/index.php/o pt/article/view/195

10. Suryani, N. D. (2013). Sistem Pencatatan Dan Pelaporan Terpadu Puskesmas. Universitas Ahmad Dahlan, 27-32. 